\title{
CIVIL LIABILITY FOR CONTAMINATION: BLUE CIRCLE INDUSTRIES PLC V MINISTRY OF DEFENCE
}

\author{
Maria Lee, Lecturer in Law, University of Central Lancashire
}

The Court of Appeal in Blue Circle Industries plc $\mathrm{v}$ Ministry of Defence ${ }^{1}$ allowed recovery of substantial damages for loss resulting from radioactive contamination of property. As the first Court of Appeal decision on the civil liability provisions of the Nuclear Installations Act 1965 , the case is clearly of interest to specialist nuclear energy lawyers.

The Blue Circle decision suggests a pragmatic approach to the definition of property damage under the Nuclear Installations Act 1965. It also illustrates that the courts may be prepared to recognise those financial consequences of contamination which extend beyond clean up. In respect of identification of property damage, the decision is notable for the contrast it provides with the earlier High Court decision of Merlin v British Nuclear Fuels Limited. ${ }^{2}$

Given that the decision concerns only liability under a particular statute, its formal precedent value is limited. Nevertheless, the Court of Appeal's consideration of the nature of the damage occasioned by radioactive contamination and the economic consequences of that contamination may be of more general interest to environmental and tort lawyers.

\section{THE FACTS}

The litigation concerned property owned by Blue Circle which adjoined the Aldermaston Atomic Weapons Establishment. Heavy rain on 6 July 1989 caused water from ponds on the Aldermaston site to overflow. The overflow passed down a stream, through marshland on the Blue Circle site and into a lake. The defendants discovered shortly afterwards that the overflow had contaminated the marshland with radioactive matter. The levels of contamination presented no threat to health, ${ }^{3}$ but were above those set under the Radioactive Substances Act $1960 .{ }^{4}$ Following some delay, Blue Circle's senior management were informed of the contamination in January 1993.5 The defendants removed the contamination at their own expense by the end of December 1994.

Blue Circle had been attempting to sell their estate since 1988, with no success. The 1993 disclosure of the contamination coincided with the negotiation of the possible sale of the site to Sun Micro-Systems Limited for around $£ 10$ million. Sun were informed of the contamination and withdrew from the negotiations. The site remained unsold at the time of the hearing. Blue Circle sought compensation for the effect of the contamination on the saleability or value of the site.

1 [1998] 3 All ER 385. The first instance decision of J Carnwath is reported at [1997] Env LR 341

2 [1990] 3 All ER 711

3 See J Carnwath at first instance at 379, cited by Aldous LJ at 392

4 Section 18 of the Radioactive Substances Act 1960 defined "radioactive waste" by reference to "radioactive matter" which was itself defined by reference to levels of radioactivity set out for different media in Schedule 3. Sections 1 and 2 of the Radioactive Substances Act 1993, which repeals the 1960 Act, now take a similar approach to the definition of radioactive waste.

5 The delay was sufficiently significant to be mentioned, see L.J. Aldous at 389. 
Blue Circle claimed damages under the Nuclear Installations Act $1965 .{ }^{6}$ They claimed that the contamination of their property was a breach of Aldermaston's duty, as a nuclear site licensee, to ensure that no

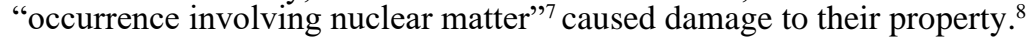

The Court of Appeal upheld the High Court decision that the contamination caused damage to property within the meaning of the statute. The first instance award of damages based on the loss of the sale to Sun plus remaining clean up costs was upheld. Additional damages, based on the reduction in market value which would have occurred regardless of the prospect of the sale to Sun, were awarded.

The statute excludes any other civil liability for damage which falls within its terms. ${ }^{9}$ Consequently, the Court of Appeal did not comment on the alternative common law claims advanced in argument. ${ }^{10}$

\section{DAMAGE UNDER THE NUCLEAR INSTALLATIONS ACT 1965 AND AT COMMON LAW}

To recover under the Nuclear Installations Act 1965, Blue Circle had to establish that they had suffered damage to property. ${ }^{11}$ This requirement had previously been considered in the High Court decision of Merlin v British Nuclear Fuels Limited. ${ }^{12}$

The plaintiffs in Merlin owned a house six miles from the nuclear reprocessing site operated by the defendants. In the context of immense public interest generated by an inquiry into the defendant's plans to extend their site, a pressure group monitored radioactivity in air at the plaintiffs' property and carried out tests on samples of house dust from the plaintiffs' property. The property was found to be subject to radioactive contamination which, it was not disputed, derived from the emissions from the defendant's site. Concerned about health risks to their children, the plaintiffs decided to move from their home. They argued that because there is a linear relationship between exposure to radionuclides and risk to health, the ingress of radionuclides constituted damage to their property. They claimed damages under the Nuclear Installations Act 1965 for the reduced value of their property.

In contrast with the decision in Blue Circle, the High Court in Merlin found that the presence of radioactive contamination had not caused

\footnotetext{
6 The 1965 Act consolidated the Nuclear Installations Act 1959 and the Nuclear Installations (Amendment) Act 1965 which were passed to reflect the requirements of the 1960 Paris Convention on Third Party Liability in the Field of Nuclear Energy (Cmnd 1211) and the 1963 Vienna Convention on Civil Liability for Nuclear Damage (Cmnd 2333); see Aldous LJ at 390. For further consideration of the UK legislation and its relationship with international law see Richard Macrory, "Nuclear installations and the statutory duty to compensate loss"[1991] 3(1) JEL 122

7 It was not disputed that the flood was such an occurrence, $\mathrm{p} 391$.

8 Section 7(1)(a). There is a similar duty not to cause "injury to any person", ibid.

9 Section 12

10 See LJ Aldous at 404. Note that at first instance J Carnwath noted that the facts may constitute "a classic example of a case within the rule [in Rylands $\mathrm{v}$ Fletcher]" at 348. See Parpworth, casenote [1997] 9 Env. Law Mgmt. 165

11 Section 7(1)(a).

12 Op cit.
} 
damage to property, ${ }^{13}$ which was held to be restricted to physical damage to tangible property. ${ }^{14}$ Possible distinctions between the two cases will be returned to below.

Contamination presents particular problems in respect of identifying physical damage to property. At one extreme, contaminants, such as acid smuts, may cause readily identifiable physical damage to property. ${ }^{15}$ In other cases, there may be simple contamination, in the sense of externally introduced material, without such readily identifiable physical change to property. ${ }^{16}$

The application of the requirement for physical damage to property in both Merlin and the leading judgment in Blue Circle by Aldous $\mathrm{LJ}^{17}$ related exclusively to the Nuclear Installations Act 1965, and is thus of limited precedent value. The strict liability regime which applies under the statute clearly differs from liability at common law. Further, actionable damage in common law claims is not restricted to physical damage to property or personal injury, as it is under the statute. Amenity-type claims, such as a claim related to the inability to continue using land for the extraction of drinking water, will often be more appropriate. ${ }^{18}$ There need be no claim that property has been physically damaged by the pollution.

Nonetheless, the classification of contamination as property damage remains an option, and can be vital, in either of the most common "toxic torts": ${ }^{19}$ private nuisance ${ }^{20}$ or negligence ${ }^{21}$. In this respect it is possible

13 Because of this finding on liability, the High Court did not consider the extent of recovery.

14 At 720 . See further below.

15 As in Halsey v Esso Petroleum Co. [1961]1 WLR 683

16 See Losinjska Plovidba v Transco Overseas Ltd and others, "The Orjula" [1995] 2 LIR 395, cited by the Court of Appeal at 393, in which it was held that contamination of a vessel by acid constituted damage sufficient to allow a claim in negligence to go ahead. It was not alleged that the physical integrity of the vessel had been altered.

17 To which the other members of the Court of Appeal did not add on this point.

18 As in Cambridge Water v Eastern Counties Leather plc [1994] 1 All ER 53. See Lord Goff at 67 and Steele, "Private law and the environment: nuisance in context" [1995] 15 Legal Studies 236 at 246. Note though that the House of Lords did not analyse in depth the nature of the damage suffered by the plaintiffs.

19 See Pugh and Day, Pollution and personal injury, Toxic torts II (Cameron May, 1994)

20 It has been argued that physical damage does not belong within the law of private nuisance, see Gearty, "The place of private nuisance in the modern law of torts" (1989) 48 CLJ 214. Gearty's argument was referred to by the House of Lords in Hunter v Canary Wharf [1997] 2 All ER 426 at 439. However, the position remains that if property damage is established, the concept of reasonable user presents less of a hurdle for plaintiffs than in an amenity claim, St Helens Smelting Company v Tipping (1865) 11 HL Cas 642 and Brenner, "Nuisance law and the industrial revolution" [1974] 3 Journal of Legal Studies 403 , at 413 to 415 . On "reasonable user" see Cross, "Does only the careless polluter pay? A fresh examination of the nature of private nuisance" [1995] 111 LQR 445 at 447 to 458 .

${ }^{21}$ Where claims for loss of amenity are not possible. Classification of damage (for example personal injury, property damage, economic loss) is connected with duty of care, see for example Clerk \& Lindsell on Torts (Sweet and Maxwell, 
that the definition of property damage in the current statutory context could influence a wider ambit of pollution claims. ${ }^{22}$ One would, though, hesitate to predict that the courts would apply the approach taken in Blue Circle if the effect would be to extend common law liability for environmental pollution without statutory intervention. ${ }^{23}$

\section{PROPERTY DAMAGE IN BLUE CIRCLE}

In Blue Circle, radioactive matter was present on the plaintiff's property. The contamination could not be separated from the soil, but there was no visible change, or scientific evidence of molecular change, to the soil. The Court of Appeal held that the contamination had caused, rather than itself constituted, damage to property. ${ }^{24}$ The court, following the approach taken by the Court of Appeal in Hunter v Canary Wharf Ltd, ${ }^{25}$ sought to identify "some alteration in the physical characteristics of the property, in this case the marshland, caused by radioactive properties ${ }^{26}$ which render it less useful or less valuable". 27

This section will first consider the "alteration" and "loss in use or value" aspects of this approach. Possible distinctions between the position in Merlin and the position in Blue Circle will then be examined.

\section{(a) Alteration}

The Court of Appeal had no difficulty identifying alteration to the physical characteristics of the marshland. ${ }^{28}$ Given that the court did not analyse the facts on damage in great detail, some effort is required to distil the factors influencing the finding on alteration from the judgment. The possible importance of both remediation and externally defined standards to the finding of "alteration" will be considered here.

\section{The importance of remediation techniques}

In identifying damage, the decision emphasises that the plutonium was "intermingled" with the soil in the marsh to the extent that it could not be separated from the soil, and that decontamination therefore required a major engineering operation involving the removal of topsoil from the site. ${ }^{29}$ The definition of "damage" on this approach appears to depend partly on the complexity of decontamination.

1995) par 7-54 on pure economic loss and Cartwright, "Remoteness of damage in contract and tort: a reconsideration" [1996] 55(3) CLJ 488.

${ }^{22}$ Even in Blue Circle the definition of damage is taken from the common law decision in Hunter v Canary Wharf [1996]1 All ER 482, see further below.

${ }^{23}$ Note Lord Goff's reluctance to extend common law principles to deal with environmental pollution, Cambridge Water v Eastern Counties Leather plc, op cit at 76. The civil liability regime under the Nuclear Installations Act 1965 would appear to be an example of the legislative activity which Lord Goff considered preferable, ibid.

24 On the distinction see further O'Sullivan, "A poor reception for television nuisance" [1996] 55 CLJ 184 at 187.

${ }^{25}$ In the Court of Appeal. Note that this point was not considered by the House of Lords, op cit. See O'Sullivan, op cit on the limitations of the decision on damage.

${ }^{26}$ As required by the statute, see LJ Aldous at 391 to 393.

${ }^{27}$ LJ Aldous at 393

${ }^{28}$ Ibid

29 Ibid 
The proposition that the need for specialist or unusual repair work can influence the definition of damage is familiar from earlier cases. ${ }^{30}$ This may lead to a circular approach where the legal definition of damage depends upon repair of that damage: it implies that if land has been remediated it must therefore have been damaged. So, if repair is not needed, is not possible ${ }^{31}$ or is straightforward, damage will not be established in this way. To look solely to the plaintiff's perception of the need for repair and the form it should take would allow the plaintiff to determine the existence of damage. So an objective view of the need for remediation is required, and yet the law appears to define property damage partly by reference to that very remediation. ${ }^{32}$

The Court of Appeal partially avoided such circularity of argument by reference to the practical impossibility of isolating and separating the radiation from the soil, that is the "intermingling" identified above. This introduces further complexity, as changes in remediation technology will mean that the types of contamination which fall within this part of the definition may change. Moreover, the practicality and economic rationality of separating contaminants from property may have to be compared with other options such as removing soil.

\section{The importance of external thresholds}

Consideration of legislative thresholds for radioactivity on land also mitigated the self-referential nature of the Court of Appeal's approach to alteration. The soil had to be removed because, as a result of the contamination, levels of radioactivity set under the Radioactive Substances Act $1960^{33}$ were exceeded in the plaintiff's soil, which had acquired the new legal definition of radioactive waste. ${ }^{34}$

Blue Circle is not unique in being influenced by external thresholds when defining damage, ${ }^{35}$ but the precise nature of the influence is not yet clear and is not explored by the Court of Appeal in its treatment of the facts.

The interaction between civil law and external standards is a significant question for both the development of environmental regulation and the role of civil liability in environmental protection. ${ }^{36}$ Blue Circle suggests that a clearly fixed external standard can influence the legal perception of

30 See Hunter v Canary Wharf in the Court of Appeal and The Orjula, op cit

31 See the consideration of Merlin, below.

32 In Blue Circle the Court was able to look to defined thresholds of radioactive pollution, on which see further below.

33 LJ Aldous at 393. Also see the more detailed consideration at first instance, at 347 et seq.

34 Under the Radioactive Substances Act 1960, LJ Aldous at 393. Note that there was a similar change of legal definition in Cambridge Water op cit. See further Steele, "Private law and the environment: nuisance in context" op cit at 246.

35 See Cambridge Water, op cit which also deals with external standards. In The Orjula, op cit the actions of regulatory authorities were relevant. In Murdoch v Glacier Metal Co Ltd [1998] Env.LR 732, the breaching of World Health Organisation standards was considered when assessing the existence of a noise nuisance, although on the facts no nuisance had been committed.

36 For a more detailed discussion see Steele, "Private law and the environment: nuisance in context" op cit and Steele, "Assessing the past: tort law and environmental risk" in Jewell and Steele, Law in environmental decision making (Oxford University Press, 1998) 
damage in a difficult case, ${ }^{37}$ even where there is no suggestion that an action for breach of statutory duty would lie solely for causing the relevant thresholds to be exceeded on the plaintiff's land. The Court of Appeal demonstrated some reluctance to look behind statutory standards, ${ }^{38}$ which thereby acquired a normative force outside their anticipated context. ${ }^{39}$

The use of external standards to define damage in a case of contamination is not without its difficulties ${ }^{40}$ not least that such standards bear no necessary relationship with environmental harm. ${ }^{41}$ Regulatory standards are set as a collective judgment on the public interest and may not be an appropriate tool for the determination of "acceptable" levels of environmental contamination ${ }^{42}$ in the sphere of individual rights in civi law. ${ }^{43}$ Further, to rely heavily on fixed thresholds implies that the common law will be unable to act effectively in cases where no thresholds have been set, or where they are weak. ${ }^{44}$

${ }^{37}$ See Layard, "Nuclear liability damage reform after Chernobyl" [1996] 5(3) RECIEL 218, at 220 on the benefits of agreeing international standards of intervention in the context of civil liability for radioactive contamination.

${ }^{38}$ On the diverse forms which standards can take, see the 21st Report of the Royal Commission on Environmental Pollution, "Setting Environmental Standards" (The Stationery Office, 1998) chapters 1 and 9.2 and Barnett and O'Hagan, Setting Environmental Standards: the statistical approach to handling uncertainty and variation (Chapman \& Hall, 1997) at 5 to 8 and chapter 2. See also Jewell, "Public law and environmental decision making" in Jewell and Steele, op cit at 81 and Howarth, "Poisonous, noxious or polluting: Contrasting approaches to environmental regulation" [1993] 56 MLR 171

39 See Steele and Wikeley, "Dust on the streets and liability for environmental cancers" [1997] 60 MLR 265 to 275 on a similar extension in the context of the identification of the individuals covered by regulation and by tort.

40 On the use of fixed standards generally in environmental regulation see for example Macrory, "Environmental law: shifting discretions and the new formalism" in Lomas, Frontiers of environmental law (Chancery Law Publishing, 1991) and Robinson, "Regulatory evolution in pollution control" in Jewell and Steele, op cit.

${ }^{41}$ Note the defendants' argument in Blue Circle, at 392 and 410. See Barnett and O'Hagan, op cit on the poor incorporation of uncertainty into environmental standards and Fisk, "Environmental Science and Environmental Law" [1998] 10 JEL 3 on some of the limitations of science in the legal process.

${ }^{42}$ For a review of the difficulties with "acceptability" of risk, see for example Fischoff et al, Acceptable Risk (Cambridge University Press, 1981) and Adams, Risk (UCL Press, 1995). See also Stanley, "Public concern: the decisionmakers' dilemma" [1998] JPL 919 and O'Riordan, Kemp and Purdue, "How the B Sizewell inquiry is grappling with the concept of acceptable risk", in O'Riordan, Readings in Environmental Psychology: Perceiving Environmental Risks (Academic Press, 1995).

43 See further Steele, "Private law and the environment: nuisance in context" op cit.

44 It has to be assumed that in a clear case of damage, the fact that there are regulatory thresholds in place which have not been breached would not alter the finding of damage. Note that criminal liability in a case of water pollution is possible even if regulatory standards are not breached, see $R \mathrm{v}$ Dovermoss, [1995] Env LR 258. Conversely, Budden v BP Oil Ltd (1980) JPL 586 suggests that meeting a regulatory standard will preclude a finding of breach of duty of care in negligence. 


\section{(b) Loss in use or value}

The second element of the test adopted by LJ Aldous in Blue Circle - loss in use or value - was satisfied by valuation evidence and the unsaleability of the estate pending remediation. ${ }^{45}$ The Court of Appeal again seems to have assessed damage by reference to losses suffered by the plaintiff, rather than seeking to identify damage as a tool to assess the recoverability of those losses. As above, a completely circular approach could be avoided by looking to external views of use or value. For example, regulatory standards may prevent the use of a borehole for the extraction of drinking water. ${ }^{46}$

If, as the decision suggests, physical alteration of property will always be necessary, it is questionable whether this further refinement of loss of use or value is appropriate. ${ }^{47}$ Contaminated property may lose value in the absence of alteration, for example due to market perception of heightened pollution risk, ${ }^{48}$ and loss in value would not in such circumstances indicate the existence of physical damage. It is disappointing that the Court of Appeal does not consider possible reasons for the diminution in value in this context. ${ }^{49}$

Loss in use or value may be a more appropriate test when considering damage to chattels, where an interference with use or value is at least more likely to be indicative of underlying physical damage rather than simple stigma. ${ }^{50}$ It is arguable that by using these criteria in the context of real property, the Court of Appeal imports into the notion of property damage considerations of "use and enjoyment of property" which are more suited to a claim for loss of amenity in private nuisance, and which add nothing to the definition if physical alteration is also required.

\section{(c) Distinguishing Merlin}

As noted above, the radioactive contamination in Merlin was not found to have caused damage within the terms of the Nuclear Installations Act 1965. The Court of Appeal in Blue Circle distinguished the cases on the basis that in Merlin "the judge did not hold that the house and the radioactive material were so intermingled as to mean that the characteristics of the house had in any way altered". ${ }^{51}$ Whilst this is the case, it could be queried whether the two sets of facts can be distinguished on this single criterion.

45 LJ Aldous at 393. Note also the first instance consideration of this aspect at 346 and 347.

46 Cambridge Water, op cit. See also The Orjula, op cit, where the regulatory authorities refused to allow the ship to leave a special berth until it had been decontaminated.

47 See also the rejection of reliance on this test in Hunter v Canary Wharf, op cit in the Court of Appeal, at 499.

48 See for example Rust v Victoria Engraving Dock Company and St Katherine Dock Company (1886) 36 Ch D 113 in the context of flooding.

49 Although the recovery of damages not directly linked to the property damage is excluded, at 401 and onwards.

50 Although it is conceivable that some chattels, particularly if a large element of safety is involved (e.g. in the sale of second hand vehicles), could be similarly stigmatised where there is no physical damage.

51 LJ Aldous at 393 
A key finding in Merlin was that the Nuclear Installations Act 1965 requires physical damage to tangible property. ${ }^{52}$ The plaintiffs in that case did not allege physical damage to the actual bricks and mortar of their house, but rather that the presence of contamination in the air space within the walls, ceilings and floors of their property constituted damage. ${ }^{53} \mathrm{By}$ contrast, Blue Circle were alleging physical damage to the soil making up their property.

The requirement of "tangible property" seems to be as important as the identification of damage. The alteration in Blue Circle was a mixing of soil and contamination rather than a chemical reaction between the two, which seems rather similar to the mixing of air and contamination in Merlin. The legal distinction between the facts of Blue Circle and Merlin must be sought in the elements of the test applied by the Court of Appeal.

In terms of "alteration", Blue Circle and Merlin are similar. In neither case does there appear to be "detectable damage to the molecular structure of inanimate objects". ${ }^{54}$ However, in Merlin there is no suggestion in the report that remediation was possible, whilst in Blue Circle removal of the soil remediated the marshland. ${ }^{55}$ Similarly, there is no suggestion in the report that any external thresholds have been breached on the Merlins' property. The latter point is made the more striking by the acknowledgement in Blue Circle that the levels of radioactivity presented no threat to health, whilst in Merlin Gatehouse $\mathbf{J}$ seems to have accepted the plaintiffs' contention that they did. ${ }^{56}$

In terms of loss in use or value, there are again similarities. In both cases the damages claimed related to the economic consequences of alleged damage. Possible distinctions may be that there was no suggestion that the Merlins' property was totally unmarketable, ${ }^{57}$ and that the Merlins' decision to sell was taken because of the contamination, rather than independently of it. ${ }^{58}$ If these distinctions are taken up in later cases, the influence of diminution in value on litigation over contamination is significantly restricted.

A final point of distinction is that Blue Circle defines damage in the context of a sudden and isolated event, a leak of radioactive material. Many cases of contamination, including Merlin, involve chronic pollution which may be a necessary and anticipated side effect of a legitimate activity. Such pollution will frequently escape condemnation by the civil courts on the basis of no breach of duty ${ }^{59}$ or no foreseeability of damage. ${ }^{60}$

52 At 720. The Court of Appeal does not comment on this part of J Gatehouse's judgment, although it is clearly significant to liability under the Nuclear Installations Act 1965, and other interpretations may have been sustainable. See further Macrory, "Nuclear installations and the statutory duty to compensate loss", op cit

53 At 720

54 At 721

55 Whether this could be called environmental remediation is debatable, see further Steele, "Remedies and remediation: Foundational issues in environmental liability" (1995) 58 MLR 615

56 At 721

${ }^{57}$ It is possible that this reflects the wider market for residential property as opposed to the unique commercial property at issue in Blue Circle.

58 Although see LJ Simon-Brown's reference to the fact that without the prospect of the Sun sale the plaintiffs would have been holding an estate worth less than it otherwise would have been, at 415 .

59 In negligence, see for example Pugh and Day, op cit at 120 to 122. 
In the strict liability regime of the Nuclear Installations Act 1965 the definition of damage is itself influenced as the courts "incline away from a construction of the Act which would result in the operator being in continual breach of the statutory duty to a possibly large number of people". ${ }^{1}$

\section{DAMAGES}

The second notable issue in Blue Circle concerns the extent of damages recoverable once liability has been established. Although again the discussion directly relates only to liability within the nuclear industry, the Court of Appeal explicitly applied "normal rules of assessment of damages". ${ }^{62}$

The property damage identified for the purpose of liability under the statute had been remediated before trial at the cost of the defendants. Blue Circle claimed the loss in value to their property which persisted after clean-up, which they alleged was due to the contamination. This claim could be interpreted as a claim for blight: the impact on property of adverse public perception of pollution, which may lead to a diminution in the value of property. ${ }^{63}$

Diminution in value of property and the cost of reinstatement of property are normal standards of assessment of compensation for damage to real property and are often seen as alternatives. ${ }^{64}$ In Blue Circle physical damage was remediated and damages were then recovered for the residual diminution in value of property. At first instance the point that financial losses which persist following remediation should be recoverable was made explicitly. ${ }^{65}$ The fact of prior remediation was not dealt with in the Court of Appeal other than as a question of fact coinciding with the breach in the chain of causation. ${ }^{66}$

Focusing on foreseeability of damage, ${ }^{67}$ the Court of Appeal upheld the first instance award for loss of the commercial opportunity represented by the chance of the Sun sale. The chance of completion was assessed at $75 \%$ and damages were awarded proportionately. More significantly, the Court of Appeal awarded an additional sum for the lesser diminution in value which the property would have incurred had there been no prospect of the uniquely valuable sale to Sun. Because $75 \%$ of this loss was covered by the award for the loss of the Sun sale, Blue Circle's damages were increased by $25 \%$ of the difference between the general pre-contamination

60 See for example Cambridge Water, op cit

61 Merlin $\vee$ BNFL, op cit, at 722

62 See Aldous LJ at 394

63 See further Lee, "Environmental blight: liability at common law" [1998] 6(2) Env Liability 56

${ }^{64}$ McGregor on Damages (Sweet and Maxwell, 1997), para 1474 and onwards but see para 1484 for cases where both measures of damages were taken into account. See also Hunter v Canary Wharf, op cit in the House of Lords at 441.

65 At 351 .

66 On which see further below.

${ }^{67}$ LJ Aldous at 394. Unlike LJ Aldous, LJ Chadwick at 406 rejected the proposition that the consequences of damage need to be foreseeable on the basis that under the statute's strict liability regime, there is no requirement even for the damage itself to be foreseeable. Foreseeability would clearly be significant in a common law claim, although it would not necessarily be dealt with in the same way as in the statutory claim. 


\section{Northern Ireland Legal Quarterly [Vol. 50, No. 3]}

market value, ignoring the Sun sale, and reduced post-contamination value. ${ }^{68}$

This is a relatively small sum in the context of the overall award, but constitutes a significant extension of the principles involved in the assessment of quantum in this case. We are no longer concerned purely with loss of a commercial opportunity, ${ }^{69}$ but consider general losses resulting from adverse market perception of property. This amounts to compensation for contamination induced blight under the Nuclear Installations Act $1965 .^{70}$

The economic consequences of contamination are potentially vast, and so once liability extends beyond physical remediation of property, as here, the limits on that liability become an issue. The limiting factors which arose in Blue Circle are considered in the following section.

\section{CAUSATION}

The defendants in Blue Circle attempted to restrict their liability on various grounds, ${ }^{71}$ which were generally unsuccessful. It seems that the prime limitations on liability will be causation and remoteness. ${ }^{72}$

\section{(a) Losses caused by extraneous factors}

The Court of Appeal strictly limited recovery to the loss caused by the physical damage, rather than blight caused by fear of future contamination or proximity to Aldermaston. ${ }^{3}$ On this approach, Blue Circle were overcompensated at first instance for blight caused by fear of future contamination as well as for blight caused by damage.

This distinction is essentially an application of the requirement that only loss caused by a tort is recoverable. ${ }^{74}$ The duty breached here is not to damage property: there is no duty to avoid blighting operations or potentially contaminating operations. The distinction may be difficult to apply in practice, particularly as actual contamination may increase market awareness of those non-tortious but injurious activities, and a remedy for blight is centred on market perceptions of property.

Disappointingly, the Court of Appeal provided no guidance on the interpretation of expert evidence in such a case. On the contrary, in the absence of any evidence on the subject, Aldous LJ drew his own conclusion on the amount of over compensation. He considered this

68 See Simon-Brown LJ at 414 to 415

69 A position clarified by the Court of Appeal in Allied Maples v Simmons and Simmons[1995] 1 WLR 1602; see Church, "Where causation ends and quantification begins" [1996] 55 CLJ 187

70 Note that recovery of these residual damages does not seem to be limited by reference to the non-marketability of the property, see Simon-Brown LJ at 414

71 Simon-Brown LJ at 410 to 411

72 See Aldous LJ at 394

73 Note that there appeared to be some stigma attached to the Blue Circle property before the incident in 1989, see 362 of the first instance decision.

74 For a recent example see Blackburn v ARC [1998] Env LR 469. See also Andreae v Selfridge [1938] 1 Ch D 1. The decisions in Rust v Victoria Graving Dock Co (1887)36 ChD 113, Hooper v Rogers [1975] Ch D 43 and West Leigh Colliery Company Limited $\mathrm{v}$ Tunnicliffe \& Hampson Limited [1908] AC 27 are cited by the Court of Appeal in the context of pure economic loss at 394, although they could equally have been used to identify the distinction between tortious and innocent losses. 
unobjectionable on the basis that expert valuation evidence is a matter of opinion which is therefore open to error in any event. ${ }^{75}$ If a rational distinction between tortiously induced blight and non-tortious blighting activities is to be maintained, some further analysis, or at least greater faith in the expert evidence, is required. ${ }^{76}$

The requirement of physical damage to property creates further difficulties. Physical damage to a neighbour's property is equally likely to result in blight. ${ }^{77}$ Similarly, if the contamination had been revealed only to Sun and only after the sale, there would have been no damage to property but the purchase of property which was worth less than the purchaser had initially thought. ${ }^{78}$ These apparent inconsistencies are not limited to environmental claims, but are fundamental to the restrictions on recovery of pure economic loss in English law, the arguments on which will not be rehearsed here.

These problems do highlight the wider point relating to environmental litigation: the type of damage. Discovery by the plaintiff is crucial to establishing damage which consists of unacceptable levels of pollution rather than obviously "broken" property. Such damage may only be discoverable by monitoring. If monitoring, as here, is carried out by the defendants, "damage" occurs at the point of disclosure. Allowing recovery for the economic consequences of such damage may dissuade potential defendants from monitoring or revealing the results of monitoring. ${ }^{79}$ This has a potentially perverse effect on the use of civil liability as a means of environmental protection. Whilst imposing liability may force the polluter to pay, it could equally reduce the disclosure and consequently the clean up of contamination.

\section{(b) Timing of the breach in the chain of causation}

Market perception of property is crucial in a blight claim, and so market fluctuations mean that the time at which liability is crystallised is particularly important. A simple assessment of damages at the date of the initial damage ${ }^{80}$ will not assist as the loss claimed is that which remains after the physical consequences of the tort have been remediated.

In Blue Circle, the Court of Appeal assessed damages immediately on remediation, when the site regained its marketability, on the basis that the breach in the chain of causation occurred when the plaintiffs regained their freedom of action in respect of the estate. This was in the plaintiff's favour due to a rising market, but Blue Circle suggests that as the defendant receives no credit for an increase in market value,${ }^{81}$ nor would the plaintiff

75 At 402

76 Note that recovery of these residual damages does not seem to be limited by reference to the non-marketability of the property, see Simon-Brown LJ at 414

77 See Simon-Brown LJ at 411

$78 \mathrm{Ibid}$. For consideration of pure economic loss in negligence, see for example Clerk \& Lindsell on Torts, op cit, para 7-54 and onwards. Note also that Aldous $\mathrm{LJ}$ at 394 declines to consider in depth the decisions in Rust $\mathrm{v}$ Victoria Graving Dock Co, op cit, Hooper v Rogers, op cit, West Leigh Colliery Company Limited $\mathrm{v}$ Tunnicliffe \& Hampson Limited, op cit and Murphy $\mathrm{v}$ Brentwood District Council [1991] 1 AC 398 on the basis that Blue Circle is not a case of pure economic loss.

${ }^{79}$ See Simon-Brown LJ at 411 on the savings made by delay here.

${ }^{80}$ This general rule of assessment is not applied across the board in any case, see McGregor, op cit, para 689 to 692.

${ }^{81}$ Although Chadwick LJ had "doubts on the matter" at 409. 
for a reasonable but unsuccessful attempt to mitigate damages by retaining property in a falling market. ${ }^{82}$

This reliance on non-marketability is not without its problems. There will usually be some price at which a property will sell, if only to speculators, and the sorts of factors which will influence marketability (such as the state of the market, the availability of other similar property or proximity to the defendant) may be unconnected with the damage. Moreover, save in terms of mitigation of damage, it is difficult to see the distinction between being unable to sell a property and being able to sell it only at an uneconomic price. It has been held that in some circumstances the economics of a sale can amount to being "locked in" to an agreement in the same way as if property is unsaleable. ${ }^{83}$ The key is whether the tort, here breach of statutory duty not to cause property damage, continues to operate.

Attempts to apply this finding on the point of assessment of damages to other cases would be problematic, as would an attempt to identify an alternative single approach to the issue ${ }^{84} \mathrm{It}$ is important to recognise that the breach in the chain of causation is a question of fact. This leaves substantial discretion on the extent of recovery for blight in the hands of the courts.

\section{CONCLUSION}

The decision in Blue Circle develops the definition of damage to property in the strict liability regime under the Nuclear Installations Act 1965. Radioactive contamination does not fit within the traditional concept of property damage in the law of torts. The Court of Appeal's approach to this issue recognises the potential of contaminants to do harm in the absence of scientific or visible evidence of alteration to property. Although here the environmental benefits of liability are probably limited to the internalisation by the polluter of the true costs of contamination, cases in which clean up depends on this approach can be envisaged.

In the absence of full analysis by the Court of Appeal, the precise position on property damage under the Nuclear Installations Act 1965 is somewhat uncertain. In particular, the Court of Appeal seems to assess damage by reference to the consequences of contamination: the facts of decontamination and financial loss. A more traditional approach would use the classification of contamination to assess the recoverability of damages.

The assessment of damages recognises that contamination may have economic consequences beyond physical remediation. Again, whilst the polluter is thereby paying for the full consequences of its actions, the absence of explicit analysis means that the future development of the law in respect of contamination induced blight is difficult to predict. ${ }^{85}$

\footnotetext{
${ }^{82}$ On which see further McGregor, op cit, para 286

${ }^{83}$ See Smith New Court Securities Ltd v Scrimgeour Vickers (Asset Management) Ltd [1997] AC 254, cited by the Court of Appeal at 399.

${ }^{84} \mathrm{Such}$ as date of damage or date of remediation.

${ }^{85}$ I am grateful to my colleague Steve Wheatley for comments on an earlier draft of this paper.
} 